Blue-wattled or North Island Crow (Callaeas wilsoni).

Orange-wattled or South Island Crow (Callaeas cinerea).

North Island Thrush (Tanagra tanagra)

South Island Thrush (Tanagra capenis).

Whitehead (Mohoua albicilla).

Yellowhead (Mohoua ochrocephela).

Black Fantail (Rhipidura fuliginosa).

Pied Fantail (Rhipidura flabellifera).

Grey Warbler (Pseudogerygone igata).

Shining Cuckoo (Lamprococcyx lucidus).

Australian Swamp Quail (Synoicus ypsilophorus).

Californian Quail (Callipepla californica).

New Zealand Quail (Coturnix novaeseelandiae).

Chukor (Alectoris graeca).

New Zealand Harrier (Circus approximans).
New Zealand Falcon or Bush Hawk (Falco novaeseelandiae).

Paradise Duck (Tadorna variegata).

Blue or Mountain Duck (Hymenolaimus malacorhynchos).

New Zealand Owl or Morepork (Ninox novaeseelandiae).

White-eye (Zosterops halmaturina).

Bellbird (Anthornis melanura).

Tui (Prosthemadura novaeseelandiae).

Kingfisher (Halcyon sanctus).

Cape Pigeon or Pintado Petrel (Daption capense).

Kakapo Parrot (Strigops habroptilus).

Takahe or Notornis (Notornis hoch stetteri).

Yellowhammer (Emberiza citrinella).

Bar-tailed Godwit (Limosa lapponica).

Spine-tailed Swift (Hirundapus caudatus).

Laughing Owl (Sceloglaux albifacies).

\title{
THE RED SQUIRREL
}

The interest of members of the Society in the fate of the Red Squirrel and its presumed supplantation by the Grey has led to an interesting inquiry. The Director-General of the Nature Conservancy, Captain Cyril Diver, very kindly got in touch with Mr. Charles Elton, of the Bureau of Animal Population, who sent for our use a report by Miss Monica Shorten of a survey carried out by her in 1944-45 on the distribution of the two squirrels. Captain Diver also consulted Sir William Ling Taylor, C.B.E., late Director-General of the Forestry Commission, who has kindly allowed us to make use of the reply he gave. We have also to thank Dr. Maurice Burton for his article "The Chequered Story of Red Squirrels" in the Illustrated London Neres of 7th April, 1951.

As Dr. Burton points out, the two squirrels occupy different habitats. The Red prefers dense woods, either coniferous or fir and oak mixed; the Grey open woodland or parkland. Only where these habitats overlap is competition between the species very likely.

Before blaming the Grey for the diminution of the Red, the past history of the Red must be borne in mind, and Dr. Burton writes of 20,000 squirrels being sold annually in London round about 1837. His conclusion is that man and not the Grey Squirrel has pushed the Red Squirrel out.

Miss Monica Shorten's survey showed that the Red Squirrel 
in 1944-45 still occupied a very large area of England and Scotland; we have no reason to think that its position has much changed, though the Grey has spread further westwards. Generally speaking, the Red only was to be found in northern and western Scotland, in Wales, in north-western England, in Cornwall, and in East Anglia. The Grey alone occupied an area roughly rectangular in shape stretching northwards for 120 miles from a line joining Portsmouth to Brighton.

The rest of England, Scotland, and Wales, except where owing to unsuitable habitat there were no squirrels, was occupied by both species.

Especially remarkable was the absence of the Grey Squirrel from an area east of a line running south-east from Kingston-onHull in the East Riding to Saffron Walden in Essex. This is about the same boundary as was found in the 1937 Grey Squirrel survey (Parsons and Middleton), but the inhibiting factor is obscure.

Supporting the theory that the presence of the Grey Squirrel does gradually exclude the Red is the fact that many areas which were shown to hold Grey Squirrels in 1937 are now shown still to hold Grey Squirrels but no Red. Too much weight must not be given to this, however, because the Red content of these areas in 1937 is not known.

In the summary of her report Miss Shorten said that the results were encouraging in showing a wider range of the native Red Squirrel than had been expected. Of the two squirrels, the Red was the more widely and thinly distributed.

For the present situation and outlook for the future we cannot do better than quote from Sir William Taylor :-

"The general decrease of Red Squirrels throughout the country is attributable to the widespread felling of conifer woods over the past thirty years and also undoubtedly to epidemic disease. Locally the species is still abundant; for instance, Reds became very numerous in Rendlesham Forest (pines), Suffolk, during the last war and after.

As an instance of natural fluctuation, the Forest of Dean was infested with Reds in the early years of the century, but when I was stationed there none could be found. They began to return by the time I left but never recovered their former numbers. From 1935 the Grey throve exceedingly only to decline again - the present population is small. In both cases squirrels were shot but mainly the fluctuations were from natural causes. Shooting has never proved more than a partial remedy for excessive populations. 
Where Reds are numerous they are very destructive, indeed when looking for telegraph poles during the war it was found that large numbers of trees had been made useless. The damage done by Reds is girdling, and consequent death and malformation of stems, also the destruction of cones and hindrance to natural regeneration.

In my opinion the Red Squirrel will again increase as the new conifer forests grow to cone-bearing age. As in the past, it will be necessary to keep populations in check if widespread damage is to be avoided. I am not among those who think the Grey will clash with the Red except in hardwood areas, nor do I think there is danger of either becoming extinct."

Finally, perhaps, we may quote from Captain Diver's summing up of the situation :-

"Looking at Great Britain as a whole there does not appear to be cause for alarm; nor is there evidence that such action as the Forestry Commission must take to protect the nation's timber crops against the growth of large populations of the Red Squirrel in the State forests, is dangerous to the continued existence of the species in this country.

If extinction were threatened, the Conservancy would certainly bring their influence to bear to avert it; and I feel sure they would get all reasonable support from the Commission."

\section{THE PRESENT STATE OF WILD LIFE CONSERVATION IN THE UNION OF SOUTH AFRICA}

(From the Director of Information, South Africa House)

Apart from sixty-one Forest Nature Reserves, with a total area of $12,906.7$ acres, the following national parks and nature reserves exist in the Union of South Africa :-

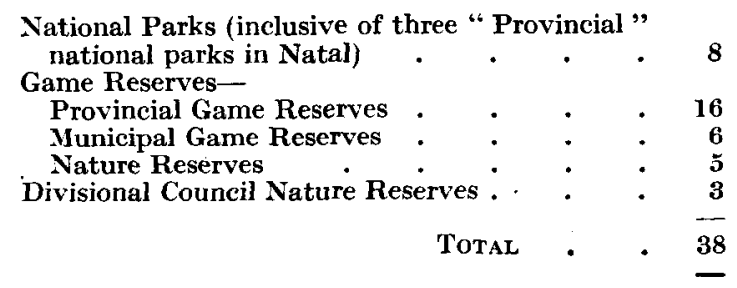

